Trinity College

Trinity College Digital Repository

Faculty Scholarship

Fall 2005

Abridging the Antiquitee of Faery lond: New Paths Through Old

Matter in The Faerie Queene

Chloe Wheatley

Trinity College, chloe.wheatley@trincoll.edu

Follow this and additional works at: https://digitalrepository.trincoll.edu/facpub

Part of the English Language and Literature Commons 


\title{
Abridging the Antiquitee of Faery lond: New Paths Through Old Matter in The Faerie Queene
}

\author{
by Chloe Wheatley
}

Sixteenth-century history may have been recorded most spectacularly in prestigious folio chronicles, but readers had more ready access to printed books that conveyed this history in epitome. This essay focuses on how Edmund Spenser (1552?-99) appropriated the rhetoric and form of such printed redactions in his rendition of fairy history found in book 2 of The Faerie Queene (1596). Through his abridged fairy chronicle, Spenser connects to a broadly defined reading public, emphasizes the deeds not only of kings but their imperial and civic deputies, and provides an alternative interpretive pathway through his poem.

Tn book 2 of Edmund Spenser's The Faerie Queene, the knights Arthur 1 and Guyon visit Eumnestes, the chronicler who inhabits the Room of Memory. While Arthur reads a dynastic chronicle entitled Briton moniments, Guyon reads "another booke, / That hight, Antiquitee of Faery lond," in which "whenas he greedily did looke; / Th'of-spring of Elves and Faryes there he fond, / As it delivered was from hond to hond" (2.9.60.1-5). ${ }^{1}$ The chronicle that Guyon reads, presumably, is the extensive

"I wish to thank the generous and helpful editorial staff and readers at Renaissance Quarterly, my colleagues at Trinity, and my friends and advisors at Columbia - David Kastan, Jean Howard, Robert Stein, and Anne Lake Prescott in particular — who have patiently commented on the many versions of this piece.

${ }^{1}$ Parenthetical citations refer to book, canto, stanza, and line numbers as found in Spenser (A. C. Hamilton's edition of The Faerie Queene). I cannot hope to do justice here to the extensive scholarship that has illuminated the relationship of the British and fairy histories to each other and to a broader historical culture. Van Es, 6, provides an elegant overview of the "very long tradition of 'reading Spenser historically" through which modern readers have been provided an "increasingly multifaceted" understanding of this poet's engagement with historical forms and issues. Woodcock, 125, reviews the various arguments that have been made about the relation of British and fairy history, with an emphasis on how "whilst most critics focus on the contrast between the respective meaning of each of the two chronicles, it is equally important to understand the relationship of 'Briton moniments' and 'Antiquitee of Faery lond"' as one of "parity." Important studies of the relationship of British and fairy history in terms of how they contrast include O'Connell; Roche; Cain; Berger. Other scholars particularly focused on the idea of Elfin history as an idealized version of human history include Williams; Mills. Anderson, 1987, 208, asserts the fairy history's ideal nature, but also argues for the presence of a complex interplay of antiquarian and "antic" energies. Fletcher stresses the complementary nature of the two chronicles; Miller denies an absolute distinction between the two as she sees traces of violence in both. Galbraith provides a more broadly conceived study of how Spenser (and, after him, Daniel and Drayton) plays with the boundary between poetic and historical discourse. 
account compiled by Eumnestes that details the lineal succession of fairy kings. ${ }^{2}$ However, the readers of The Faerie Queene are not provided with direct access to this text. The poem's narrator, running rapidly through the entire course of fairy history in a mere seven stanzas, instead presents an epitome, or abridgement, of his source (figs. 1-2). ${ }^{3}$ This summary of Elfin Antiquitee draws attention to the distinct potential of the summary form, and marks Spenser's awareness of the role such redactions were playing in the dissemination of Renaissance history. Specifically, the abridged Antiquitee renders up what both detractors and apologists intuited about the epitome as a text that could reach a wider readership at the same time that it adapted or even replaced the meaning of its more expansive sources. ${ }^{4}$ Spenser in effect invites the reader to treat the historical epitome as a form taking a rightful place next to the other historical forms chronicle, chorography, genealogy, and prophecy - that enrich the historical texture of his poem and provide models both for action and understanding. ${ }^{5}$

${ }^{2}$ For the purposes of this article, the terms elf and fairy (as well as variants such as elfin and faerie) will be considered interchangeable.

${ }^{3}$ I treat as roughly synonymous the terms abridgement, summary, and epitome, a choice justified by looking at the prefatorial remarks of chosen historiographers as well as at lexicons of the period. For example, Minsheu treats as synonymous the terms, "Epitomy, abreviation, or abridgement," and (695) defines sumarie as "abreviation." Scholars have noted the fairy history's brevity, if not its specific generic association with the printed epitome. Rossi, 57, observes that fairy history is "compress[ed]" and "rush[es] literally from ruler to ruler." Christian, 77, enumerates how the fairy history traces lines of "spiritual rather than biological kinship," and can be seen as situating Elizabeth I within a spiritual family that includes Deborah and the kings of Judah. Woodcock, 118, draws attention to the parasitic nature of the fairy history, arguing that the narrator, in emphasizing the history's mediated nature, draws attention to the poem's "eulogist" construction of a foundation myth for Elizabeth I. Woodcock sees the act of mediation as a peculiarly poetic trait while I see Spenser acknowledging, as well, the potential of the mediating stance of the historical epitomator.

${ }^{4}$ For a discussion of Spenser's readership, see Murrin, 9, who discusses the readership for Elizabethan romances, and argues that while Spenser "dedicated his romance to Queen Elizabeth, [he] had in mind a larger, more variegated audience than the aristocracy alone."

${ }^{5}$ Van Es has produced the most extensive study to date of Spenser's evident interest in how a wide range of forms "played an important role in the construction of historical meaning"; he treats chronicle, chorography, antiquarianism, euhemerism, analogy, and prophecy as "useful categories through which to explore the implications of this fact" (17). More specifically, Van Es sees the fairy epitome as shaped in the image of the euhemeristic text. Stewart and Sullivan, 228, explore how fairy history figures the intersection of public historical knowledge and individual behavior, "including the most basic forms of bodily self-regulation." Summit focuses on how the fairy history reflects the profound ruptures that occurred at the institutional level during the Protestant Reformation. 
Cant. $X . \quad$ the Faery Queerit.

But Guycn all this while his booke did read,

Ne yet has ended : for it was a great

And ample volume, that doth far excead

My leafure, fo long leaues here to repeat:

It told, how firft Prometheus did create

A man, of nany parts from beafts deryu'd,

And then fole fire from heuen, to animate

His worke, for which he was by Iouse depryu'd

oflife him felf, and hart-Atringsof an Aegle ryu'd.

That man fo made, he called Elfe, to weet

Quick, the firft author of all Elfin kynd:

Who wandring through the world with wearie feet,

Did in the gardins of Adonis fynd

A goodly creature, whom he deemd in mynd

To be no earth'y wight, but either Spright,

Or Angell, th authour of all woman kynd;

Therefore a Fay he her according hight,

of whom all $F$ aryes fpring, \& fetch their lignage right.

Of thefe a mighty people fhortly grew,

And puiffant kinges, which all the world warrayd,

And to them felues all Nations did fubdew :

The firt and eldeft, which that fcepter fwayd,

Was Elfin, him all India obayd,

And all that now America men call:

Next him was noble Elfinars, who laid

Cleopolis foundation firft of all:

But Elfiline enclord it with a golden.wall.

Hisfonne was Elfinell; who ouercame

The wicked $G$ obbelines in bloody field:

But Elfant was of moft renow med fame,

Who all of Chriftall did Pauthes build:

Then:

FIGURE 1. Edmund Spenser. Page 345 of The Faerie Queene. STC 23081. London, 1590. By permission of the Folger Shakespeare Library. 


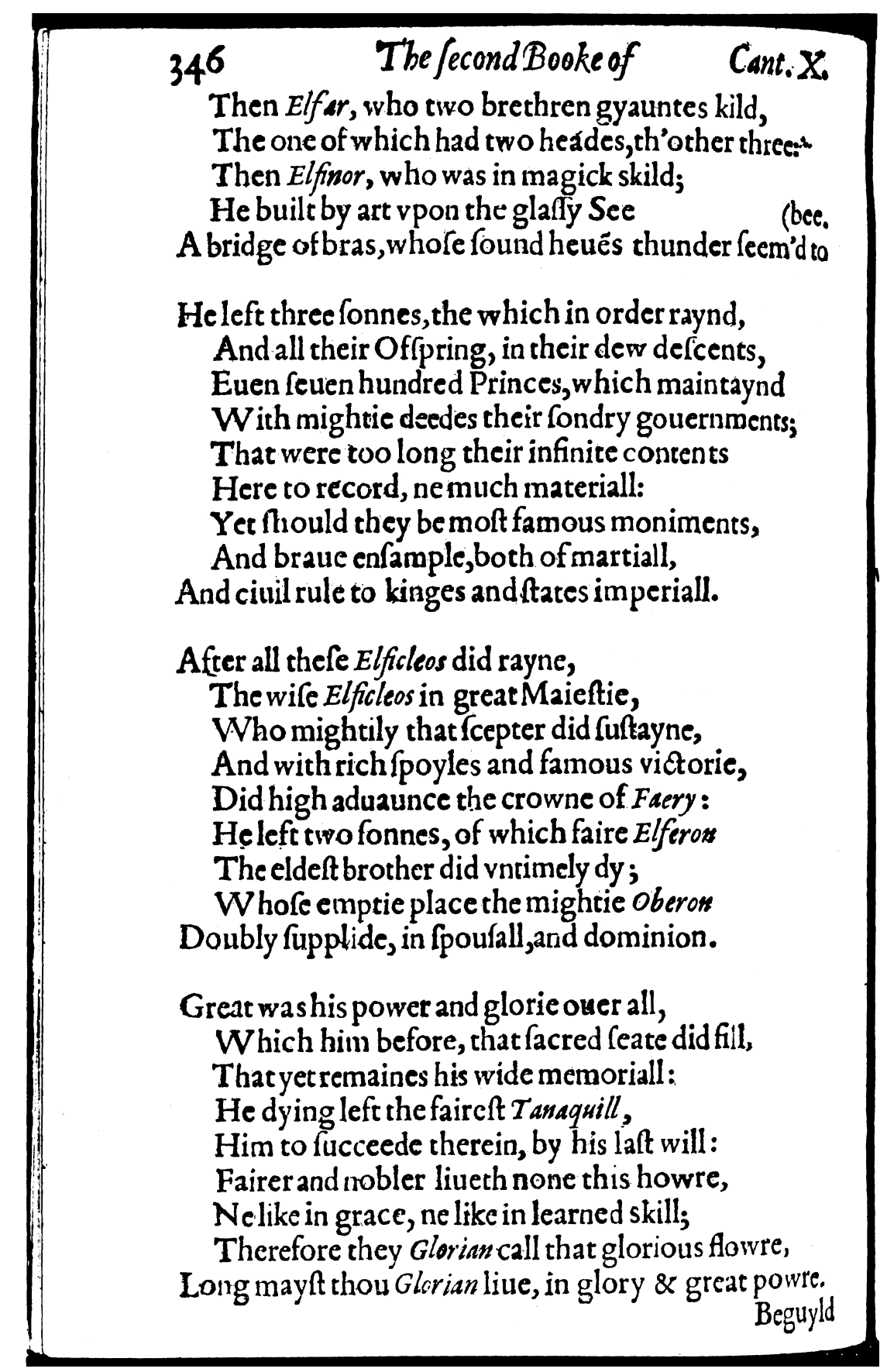

FIGURE 2. Edmund Spenser. Page 346 of The Faerie Queene. STC 23081. London, 1590. By permission of the Folger Shakespeare Library. 
Through his seven-stanza Elfin history, Spenser gestures quite specifically toward those rhetorical and print practices associated with the creation of epitomes. Humanists understood the epitome as an important byproduct of those rhetorical techniques by which one gained mastery of texts by rewriting them. According to Roger Ascham (1515-68) in his work The Scholemaster (1570), epitome refers to a type of exercise - along with translatio, paraphrasis, metaphrasis, imitatio, and declamatio - that a student could use to supplement reading and encourage eloquence: "This is a way of studie, belonging, rather to matter, than to wordes: to memorie than to utterance: to those that be learned already ... Epitome, is good privatelie for himselfe that doth worke it, but ill commonlie for all other that use other mens labor therein: a silie poore kinde of studie, not unlike to the doing of those poore folke, which neyther till, nor sowe, nor reape themselves, but gleane by stealth, upon other mens grownds." Although humanists emphasized the importance of having students produce their own summaries as a way to secure their understanding of a subject and to exercise their rhetorical flexibility, there is also evidence that teachers provided their students with readymade epitomes. For example, Sir John Cheke used upon his charge Edward VI "a tabular summary" summarizing the emperors and consuls of Rome. ${ }^{7}$ A more general reading public was also increasingly targeted as a viable market for predigested texts. Some of the subjects printed in epitome before 1580 included rhetorical handbooks, legal digests, and redactions of moral philosophy, as well as works by authors ranging from Cicero and Galen to Vesalius. ${ }^{8}$ By far the most popular printed epitomes were universal, national, and Roman histories. At the turn of the seventeenth century writers sought out various strategies of summary, abridgement, and verbal compression to feed a growing taste for

${ }^{6}$ Ascham, Oiir.

${ }^{7}$ Baldwin, 1:562. The epitome as a pedagogic form would have been available to Spenser through his grammar-school training. While Richard Mulcaster, the master of the Merchant Taylor's school (which Spenser attended), published a treatise on the training of mind and body, unfortunately no curriculum is extant from the school in this period. See ibid., 575, for description of the kinds of summaries that would have been read by students at Eton and Westminster.

${ }^{8}$ Some specific titles include The Abridgement of the Booke of Assises; Anthony Scoloker's translation out of Dutch of $A$ Bryefe Summe of the Whole Byble; Wolfgang Capito's An Epitome of the Psalmes; a translation of Cicero, Ascham, and others by Abraham Fleming entitled A Panoplie of Epistles, or, A Looking Glasse for the Unlearned (including in quire IA-B an "epitome of precepts whereby the ignoraunt may learne to indite"); and John Jones's translation of Galens Bookes of Elementes, As They Be in the Epitome. Vesalius produced a twenty-one-page Epitome of his 600-page anatomy book De Humani Corporis Fabrica; the Compendiosa Totius Anatomie Delineatio is a plagiarized English version of Vesalius's work that draws on this epitome. 
history books, producing prose summaries, broadside lists of rulers, pictorial summaries, versified accounts of important events, and even books of devotion that helped the reader commit key historical dates to memory. In fact, it is possible that between 1572 and 1583 Spenser himself contributed to this trend by working with the publisher Henry Bynneman to produce a compendium of English chronicles entitled De Rebus Gestis Britanniae.

The needs driving the printed production of such texts were on one level quite pragmatic. It was clear that large folio histories such as Raphael Holinshed's Chronicles, while capacious in their social imagination, could only reach a small readership due to their sheer bulk and expense. Much more readily marketable to a broadly defined reading public were those octavo or smaller texts that claimed to summarize such compendious sources. ${ }^{10}$ For example, in the late 1540 s Thomas Cooper produced a modified version of Thomas Lanquet's universal chronicle with interpolated English source material. Cooper advertises this Epitome of Chronicles as a summary of many texts. John Stow also published many editions of his Summarie of English Chronicles, which promise to compile only the most necessary material that Stow had found in many different "writynges of antiquities, and other, who reaped great abundance of knowlege and filled their bookes full therwith." ${ }^{11}$

That Spenser means the reader to think of his seven-stanza version of Antiquitee as part of this family of printed redactions is made clear in his appropriation of the rhetoric of time management found in many epitomes. Cooper claims that his Epitome was designed for the use of "prudent governours ... whiche for their manifold affaires and businesses, have but small tyme of leisure." ${ }^{12}$ Such evocations of the benefits of the short text would become increasingly ubiquitous through the turn of the seventeenth century. The dedicatory epistle of An Epitome of Ortelius His Theatre of the Worlde, for example, claims that the author "in his discourses is unlike the greatest part of our travellers, who with their tedious \& fabulous narrations will bring either deafnes to your eares or slumber to your eyes. But this man speakes nothing but matter, and that so succinctly, as by his conference you

${ }^{9}$ Carpenter, 64. Many thanks to the $R Q$ reader who directed me to the existence of this epitome and to Carpenter's essay.

${ }^{10} \mathrm{My}$ claim for the cultural importance of these small books of history has been instigated in part by Helgerson's 1992 claim for the central significance of England's paper monuments.

${ }^{11}$ Stow, $\mathrm{A} 3^{\mathrm{v}}$. Although I have attempted throughout to remain faithful to the spelling of the original texts I have quoted, I have also substituted modern $s$ for italic long $S, W$ for $V V$, and have expanded contractions that have been in the original represented by a tilde.

${ }^{12}$ Lanquet, $\mathrm{A} 3^{\mathrm{v}}$. 
may reap delight, \& yet not hinder your affaires of importance or recreation." ${ }^{13}$ Epitomists learned to emphasize the value of their works for "such, as either want leisure to reade or meanes to provide larger Volumes." ${ }^{14}$ The narrator of The Faerie Queene uses this type of rhetoric when in book 2 he claims that the infinite source he summarizes "was a great / And ample volume, that doth far excead / My leasure, so long leaves here to repeat" $(2.10 .70 .2-4)$.

In explicitly defining his fairy history as an abridged text, the narrator invites broader questions about the epitome's cultural function. First of all, because the narrator has purportedly chosen to replace the infinite fairy chronicle with its epitome, the reader is invited to wonder about what historical details may have been lost in the process. Ascham complains that many epitomes ultimately replaced their originals, and in this way could teach only "this wise lesson, that a man ought to beware, to be over bold, in altering an excellent mans work." 15 There existed a humanist fear that dependence on prefabricated epitomes encouraged a related sort of mental deterioration as readers used epitomes to circumvent more laborious intellectual endeavors. Spenser seems to have had similar concerns about the potential misuse of the epitome as it is included in book 2, which is filled with examples of Guyon mismatching aphorism to experience. ${ }^{16}$

However, Spenser also chose to incorporate an epitome within his poem during a period in which understanding of the epitome's function was undergoing a profound shift. While he acknowledges the traditional objections, Degory Wheare (1573-1647) in his seventeenth-century treatise on the reading of history stresses the value of epitomes: if the reader wants to gain a sense of "the whole," an epitome can "draw in [the reader's] mind an Exemplar or Idea of the whole body of the Universal History, which he may contemplate with ease as it were at once." ${ }^{17}$ Defenders of the

${ }^{13}$ Ortelius, $\mathrm{A} 2{ }^{\mathrm{r}}$.

${ }^{14}$ Rogers, title page.

${ }^{15}$ Ascham, Niiir.

${ }^{16}$ For a more extensive discussion of how book 2 engages with short forms and the problems of the intellectual shortcuts they invite, see Webster.

${ }^{17}$ Wheare, 39. According to the Dictionary of National Biography, 58:405, in 1622 Degory (or Diagory) Wheare was made the first professor of modern history at Oxford, "the donor [of the endowed chair] specifying that he wished Wheare to lecture on the epitome of Roman history by Lucius Annaeus Florus." Wheare's book on historical method began as a Latin dissertation entitled De ratione et methodo legendi historias which he delivered at Oxford in 1623 and printed that same year. The treatise went through multiple editions, including the 1685 English translation from which these quotations have been taken. 
epitome emphasized that a prefabricated redaction could provide a kind of conceptual map able to lead readers "into the pleasant Fields of History." 18 Rather than seeing the epitome as a disgraceful shortcut circumventing study, writers began to treat the epitome as a key point of entry into spatially conceived texts or bodies of knowledge.

Comparison of the prefatorial rhetoric used to introduce a sixteenthcentury (and a later, seventeenth-century) edition of a well-known Roman epitome illustrates quite well the change in attitude that occurred during this time. In his 1578 translation of The Abridgement of the Historyes of Trogus Pompeius Arthur Golding explains his notion that "Trogus Pompeius wrate the Histories of the whole Worlde; from the begynning of the monarchy of Assyria, unto the reigne of Themperor Augustus. Thabridgemente of whose woorkes gathered out by Justyne (who partly by his owne travel but more by the decaye and losse of his Aucthoure Trogus, obteined the name of a famous historiographer)."19 A more generous assessment of the epitome, however, can be found in another translation, one century later, of the same Roman source: in the 1682 edition translator Robert Codrington argues that "A great Task it was in Trogus Pompeius, to have digested so great a Subject in so great a Volume: but a greater task it was in Justin, to have contracted it into so little." Justin is no longer condemned for his parasitic appropriation but praised for his "acute dexterity" and felicitous marriage of "Perspicuity" with "Brevity." 20

Spenser's epitome lies balanced between these two fundamentally opposed attitudes, at once evoking a residual distrust of the prefabricated epitome and anticipating its emergence as a powerful interpretive tool. Spenser's interest in the epitome's formal potential is marked most clearly through his choice to juxtapose the fairy epitome against Briton moniments, which conveys the same type of historical matter in a much more capacious chronicle mode. When attuned to the distinctive historiographic qualities of each, the reader can see how efficiently Spenser has captured in poetic form the epitome's most obvious potential: its ability to create a more complete impression than the more comprehensive chronicle that precedes it. In its carefully partial nature, the fairy epitome provides the reader with a vision of the whole.

Briton moniments, the text that Arthur reads in the Room of Memory, relates the vicissitudes of British history from the period of Brute's arrival to the reign of Uther. The version of this history recited by the narrator in

\footnotetext{
${ }^{18}$ Wheare, 40.

${ }^{19}$ Justinus and Trogus, $\mathrm{A} 6^{\mathrm{r}}$.

${ }^{20}$ Justinus, $\mathrm{A} 3$.
} 
book 2, canto 10 evokes with a high degree of specificity the formal properties of the dynastic chronicle, a mode of history writing that we tend to understand as an account of the past which, while incomplete or openended in certain respects, strives for a kind of narrative coherence. ${ }^{21}$ Like an annalistic account, Briton moniments is subject to the tyranny of chronology, an issue highlighted by the supposed transcription breaking off at the point at which it would have narrated contemporary events, ending midsentence

[w]ithout full point, or other Cesure right,

As if the rest some wicked hand did rend,

Or th'Author selfe could not at least attend

To finish it (2.10.68.3-6)

and leaving the reader half offended and half pleased by the "wonder of antiquity" (2.10.68.9). Yet, like a more fully narrativized history, the conceptual categories of territory and dynasty serve, at least in part, as principles of narrative propulsion and cohesion.

Briton moniments begins with a "decided interest in the land and its acquisition of names" - with an emphasis, in other words, on territorial conquest and on the way in which naming serves to intertwine the terms of geography and political rule. ${ }^{22}$ The landscape is literally marked by the names of the conquerers. Corineus, assigned territory "for his worthy lot," calls his land "Cornewail" (2.10.12.5); "And Debons shayre was, that is Devonshryre" (2.10.12.6); finally, "Canute had his portion from the rest, / The which he cald Canutium, for his hyre; / Now Cantium, which Kent we commenly inquire" (2.10.12.7-9). The principle of order that follows the act of conquest is one in which the conquerer passes the conquered territory down to his ancestors. At the same time that it strives to articulate lineal succession as a principle of unity, however, Briton moniments makes acutely evident the vulnerability of a dynastic political ideal. External threats such as the problem of subsequent conquests of land and people by Danes, Saxons, Romans, and Normans - endanger the continuity of British rule. Even more threatening are the conflicts that arise from internal causes and seem built into the very principle of rule by primogeniture. Brute may

\footnotetext{
${ }^{21}$ As White, 5, explains, while "annals represent historical reality as if real events did not display the form of a story" and narrative histories endow the past with the coherence of a beginning, middle, and end, the chronicle "represents [reality] as if real events appeared to human consciousness in the form of unfinished stories." Woodcock, 128-29, analyzes extensively the degree to which the Spenserian narrator adopts specific narrative features from historical sources such as Geoffrey's Historia.
}

${ }^{22}$ O'Connell, 75. 
conquer Albion and bequeath it to his three sons, but subsequent generations ultimately fail to sort out questions of territory and succession. For example, Gorbud is overthrown by his sons Ferrex and Porrex, who ambitiously "unto them twayne / Arraught the rule, and from their father drew" (2.10.34.7-8). First they overthrow the orderly succession of rule from father to son, and then they fall into contention with each other; thus, after 700 years, Brute's lineage is ended by fraternal strife.

Elfin history begins with conquest as well. Unlike the British, the fairy rulers dispense rather handily with possible political encroachments from the outset by conquering "all the world" (2.10.72.2). Potential problems remain, however, regarding issues of internal rule and dynastic continuity. For example, at the dead center of the summary account of this "mighty" (2.10.72.1) fairy race, the narrator notes that Elfinor

left three sonnes, the which in order rayned,

And all their Ofspring, in their dew descents

Even seven hundred Princes, which maintayned

With mightie deedes their sondry governments. (2.10.74.1-4)

This summary seems unproblematic at first glance, but quite implausible when the reader actually attempts to visualize the political reality that Spenser means to convey. How, exactly, was the "order" of fairy rule devised and maintained among these three sons? What, exactly, was the relationship between the subsequent 700 princes? Is the reader to understand their "dew descent" as inter- or intragenerational, as successive in time or simultaneous in space? If in fact these 700 princes were brothers and cousins and not fathers and sons, how were questions of succession settled among them? The reader is given no way to resolve such questions, as the narrator appropriates a conventional prefatorial caveat found in the typical sixteenth-century epitome, claiming that his source text is "too long" in its "infinite contents / Here to record, ne much materiall" (2.10.74.5-6).

Spenser's evocation of the due descent of 700 princes echoes the narration in Briton moniments of the 700 years in which Brute's progeny reigned before that lineage was broken by fraternal strife. The summary note of the 700 princes also evokes, as it multiplies a hundredfold, the possibility of the kind of dynastic contention that plagued pre-Tudor England in the fourteenth and fifteenth centuries as Edward III's seven sons and their descendents competed for the English crown. When Spenser claims that the "mightie deeds" of Fairyland's princes are too long to record, although they should "be most famous moniments, / And brave 
ensample" (2.10.74.7-8) to future readers, he gestures towards (at the same time that he effectively shuts down) the details of a dynastic historiography that could very well contain similar overlapping claims: ambiguities of intermarriage, claims through the female line, even regicide, fratricide, and deposing of rightful kings.

While in its economy of form the abridged chronicle downplays the details of dynastic succession, it also manages, through its preservation of key details, to enact a subtle shift in historiographic emphasis. While initially it seems a narrowly focused narrative of dynastic continuity, the abridged Antiquitee in fact focuses attention upon what actions, in aggregate, constitute the fairy empire. ${ }^{23}$ Stanzas $71-76$ of book 2 , canto 10 prove how the practice of quick reading encourages the reader to see as dynastically continuous an account that actually strays from the exact articulation of lineal succession. Elfe, Spenser tells us, was the first author of all "Elfin kynd" (2.10.71.2). Like a good epic traveller, Elfe wanders until he finds "th'authour of all woman kynd" (2.10.71.7) and with her founds a race of "puissant kinges" (2.10.72.2). At first, it seems that Elfin kings rule the world in unbroken dynastic succession: the narrator relates that "The first and eldest, which that scepter swayd, / Was Elfin" (2.10.72.4). This inaugural invocation of "the first and eldest" implies that an orderly and equally perfect narrative of primogeniture will ensue, in which the rule of the world will be passed down from father to eldest son. But the reader looking for a strictly focused recitation of the passing of the reins of power from father to son (or even to daughter) will be disappointed as the question of lineal succession proves to constitute only a very small part of an already very small history. Elfe may be the clear founder of a fairy "lignage right" (2.10.71.9), but mingled in among dynastic references to successive sons are figures whose claims to fame lie most explicitly in their actions. Narrative emphasis falls in particular upon those who help through their military prowess to maintain a fairy empire by overcoming "wicked Gobbelines in bloody field" and by killing "brethren gyauntes"

${ }^{23}$ While it is imperative that we not introduce anachronistic notions of empire to our study of the sixteenth century, it is clear that empire - the vernacular for imperium - was a concept familiar to early modern readers through the examples and texts of Roman history and literature. Armitage, 104, notes that while "only in the mid-nineteenth century did 'empire' become a shorthand for its late-coined cousin imperialism,"' nonetheless "the avoidance of anachronism should not disable inquiry into the early-modern origins of the later European empires; instead, it shows the wider conceptual field within which contemporaries debated conceptions of order, hierarchy, independence, and political community." 
$(2.10 .73 .2,5)$. Another category of notables consists of those who contribute to the infrastructure of fairy civilization through civic foundation and the construction of walls, buildings, and bridges. ${ }^{24}$

In both its summarizing form and its emphasis on acts of conquest and edification, the abridged Antiquitee resembles epitomes of Roman history such as Eutropius's Breviarium, a fourth-century summary of Roman history that was translated into English in 1564 by Nicholas Haward. An abridged account relating the history of the Roman Empire from the founding of Rome to the death of Valens's predecessor Jovian, the Breviarium contains details that emphasize the deeds of figures like Severus, of whom it is said that in addition to waging "sundry battails," he was also "reverenced for his civil policy" - specifically, he "repaired manye thynges throughe out the Romain Empyre" and in Britain "caused a trenche to be cast from sea to sea." 25 Sergius Galban is another figure described as one who even as a private man "demeaned his life worthely both in Martiall actes and also in civyll policy"; Trajan, too, "purchased great glory and renowne both for civil and also Martial policy."

That Spenser deliberately echoes Eutropius is a provocative but unverifiable possibility. Certainly, the verbal parallels found between the two works suggest Spenser's interest in how a summary of empire could be used to assert the central importance of the acts of exploration, conquest, settlement, and plantation. ${ }^{27}$ The title page of Haward's translation makes clear the more general association that was already being made between the imperial summary and the act of imperial maintenance: Haward makes much of the Breviarium's status as a history including not simply the order and succession of kings but also the "sondry gestes $\&$ actes of many famous Princes and valiaunt Captaines" in the outlying territories of a Roman empire. ${ }^{28}$ If translatio imperii can be taken in its broadest sense to mean "the translation of imperial authority," then Haward's edition makes clear

${ }^{24}$ Manley, 182, argues that a "creative tension lies at the heart of Spenser's Faerie Queene, in which the image of the 'most royall queene or empresse' jostles with a vision of 'The fairest City ... that might be seene' (1.10.58)." He sees the poem as linking "by way of double determination" a "sphere of epic action to its royal Tudor patron and the epic theme of translatio to bourgeois aspirations of London's citizen class."

${ }^{25}$ Eutropius, $1564,103^{\mathrm{v}}-104^{\mathrm{r}}$.

${ }^{26}$ Ibid., $77^{\mathrm{r}} ; 86^{\mathrm{v}}$.

${ }^{27}$ For an important account of how a small but significant segment of the Elizabethan elite - including Sir Walter Raleigh, William and Robert Cecil, Sir Francis Walsingham, Sir Christopher Hatton, the Sidneys, and Lord Grey — engaged in such projects in both the New World and Ireland, see Read.

${ }^{28}$ Eutropius, 1564, title page. 
how the translation of not simply political and textual, but also social authority came to be associated with Eutropius's summary. ${ }^{29}$ This is particularly manifest in the ultimate promise of the 1564 title page that Eutropius's history is "ryght plesant and profitable to be red, marked and folowed of all men." 30

One important difference remains between Roman and fairy histories, however. Whereas the events delineated in the Roman epitome lie in the distant past, the events of the fairy epitome seem to be projected into England's future. This temporal positioning is implied in the proem to book 2, where the narrator claims that just as Peru and Virginia existed well before Europeans discovered their existence, so too Fairyland may be a world within the world as yet to be revealed to English eyes: the New World existed, "when no man did [it] know":

Why then should witlesse man so much misweene

That nothing is but that which he hath seene?

What if within the Moones faire shining spheare,

What if in every other starre unseene

Of other worldes he happily should heare?

He wonder would much more, yet such to some appeare. (II.Proem.3)

As David Read puts it, "Spenser is not writing the past history of regions that are known to the visionary poet in the present and will be revealed in the future. He is writing the history of the future itself, of the as-yetundiscovered inheritance of England ... Fairyland is there, rich with promise, waiting to be possessed." ${ }^{31}$ More precisely, Spenser makes a special point to summarize this history of the future. The specific appeal of the fairy epitome lies in its suggestion that the future empire will be so secure, so total, that it will be possible to epitomize it in a casual, nonprophetic, and distinctly bureaucratic manner.

The epitome of fairy history thus enacts an important modification to

${ }^{29}$ It is perhaps not surprising that Eutropius, 1684, A4 ${ }^{\mathrm{r}}$, includes the following epistle from Eutropius to Valens: "According to your Serene Pleasure, I have drawn up, in a short Narrative, successively from the Building of the City to your time, the Roman Transactions, which have been remarkable, both Military and Civil . . that your Divine Mind may please it self in this to have imitated the Actions of these Illustrious Persons, in the Administration of your Empire, before they were known by reading." Galbraith, 52-74, provides an important discussion of how the concept of translatio imperii was used by Spenser to figure the fraught relation of England and Rome; particularly interesting is his emphasis on how a straightforward comparison of The Faerie Queene to Virgil's epic model does not do justice to the complexity of Spenser's engagement with Rome. See also Curran on this subject.

${ }^{30}$ Eutropius, 1564, title page.

${ }^{31}$ Read, 21. 
the most well-known and well-credentialed way in which poets could create historiographic meaning. Following Virgil, poets with epic ambition narrated dynastic prophecies in which power flows along the lines of genealogical succession, culminating in the foundation of a future empire. In such accounts the future empire coincides with the present political reality experienced by the maker of the epic and his contemporary audience. Thus, for example, in book 6 of the Aeneid Virgil rewrites Roman history as a historical prophecy related by Anchises to Aeneas in the Underworld, and this prophecy concludes with a reference to Augustus. Obviously a means by which to flatter a patron, the formulation of history as prophecy also serves as an apt means by which to cast the present as the "culmination of a course of events set in motion in the remote past." 32

Spenser imitates this Virgilian model most directly in book 3, canto 10 of The Faerie Queene, in which Merlin relates to Britomart a prophetic account of the future of Britain that she will help to perpetuate through her marriage to Artegall. Merlin functions as a persuasive rhetor who shapes the tumultuous history of British kings into an account that awakes in Britomart an understanding of the role her private desires will play in the unfolding of a public history that will culminate in the reign of Elizabeth I. The epitome of fairy history, on the other hand, has the potential to produce a wholly different historiographic effect: casting the fairy past in the mode of historical summary enables the narrator of The Faerie Queene to speak securely of a future that is truly unknown. Whereas the typical epic prophecy provides the reader with the pleasure of seeing the present as the projected future of an earlier historical time, the Elfin history provides the pleasure of thinking about a very uncertain future as an already accomplished and textualized (even summarized) past.

The analysis above has suggested that the abridged Antiquitee is amenable to a variety of reading strategies. A more cursory reading produces the dynastic summary that one expects, while closer attention reveals a more broadly defined imperial whole. Nonetheless, while their topical focus is quite different, these two readings are both driven by a fundamental assumption that the epitome form serves as a historiographic shortcut that, for better or worse, circumvents the sociopolitical complexities of both the perpetuation of dynasty and the foundation of empire. An even more careful meditation upon the abridged Antiquitee makes clear how precisely and economically it delineates a qualitative difference between the two types of action, martial and civil, that constitute the fairy empire.

${ }^{32}$ Fichter, 2. O'Connell discusses specific Virgilian aspects of The Faerie Queene. See also Helgerson, 1983, on Spenser's idea of a Virgilian literary career. 
Specifically, consideration of the grammatical constructions used to bind together the fairy epitome's elements reveals the care with which the narrator recites various martial and civil acts within the framework of a succession of value rather than of time. For example, the last three lines of stanza 72 relate that "Next ... was noble Elfinan, who layd / Cleopolis foundation first of all: / But Elfiline enclosd it with a golden wall." The narrator's choice to signal the succession of one king to the "next" using the oppositional conjunction but suggests that the act of initial conquest that enabled the founding of the city has been superceded in some important way by the act of civic edification. ${ }^{33}$ Spenser uses this same grammatical construction again in the next stanza, where the sentence structure of the first four lines parallels that found in the previous stanza: Elfinell may have overcome "The wicked Gobbelines in bloody field: / But Elfant was of most renowmed fame, / Who all of Christall did Panthea build" (2.10.73.2-4). The conjunctive but again sets up terms of comparison that articulate a qualitative hierarchy of actions that accrue "renowmed fame." As the reader becomes habituated to thinking about different historical acts in these terms, the repeated then also begins to transmute:

Then Elfar, who two brethren gyauntes kild,

The one of which had two heads, th'other three:

Then Elfinor, who was in magick skild;

He built by art upon the glassy see

A bridge of brass, whose sound hevens thunder seem'd to bee. (2.10.73.5-9)

Then shifts from meaning soon after or "next in order of time" to "meaning 'next' in sense of 'beyond' or qualitatively 'more than' what precedes it." 34

Reworking the temporal progress of one's sources was a typical rhetorical strategy for the epitomist. In fact, the epitome's economy of form invites this fundamental redistribution of chronologically ordered matter. Wheare explains, for example, how the works of Florus are not strict replicas in miniature of Livy at all, as they have rearranged the matter of history along thematic rather than temporal lines: "[Florus] digests his Relations by Heads and Species, rather than times, separating things of like Nature, from those of a different: separating for Example Wars from Conspiracies, and civil Discords from Military Expeditions; in short what a great Antiquary has said [in defense of another writer] I should willingly offer in the behalf of Annaus Florus, no man can be supposed so ignorant

\footnotetext{
${ }^{33}$ For a discussion of the tautologies encoded in Spenser's use of but see Anderson,
} 1982.

${ }^{34} O E D$, “then,” adv., II.3.a.; II.3.b. 
in Chronology as that he can expect to find in Florus an exact Series of the Fasti, as if he were a sworn Accountant." ${ }^{35}$ Spenser simply takes the next logical step, inviting qualitative consideration of elements of history that have been taken out of the chronological grid and redistributed according to thematic topic or "place."

The reader who studies the syntactic cues found within the abridged Antiquitee is invited to think of the epitome as a tool by which to internalize specific criteria of judgement that can then be applied to other complex texts and bodies of knowledge. The epitome of fairy history, in other words, functions as a historiographic variation on what C. S. Lewis identifies as "allegorical cores," significant set-pieces that serve as compressed nodes of access to a greater and more complex whole. ${ }^{36}$ In fact, the precise verbal echoes found in books 3 and 5 suggest that the epitome of fairy history could function as a guide by which to judge the larger matter of The Faerie Queene itself, particularly its more diffuse representation of a desired but difficult-to-achieve transition from martial to civil rule.

The parts of The Faerie Queene that Lewis identifies as allegorical cores render up in relatively compressed form the issues, themes, and tropes that are fleshed out, and at times complicated, in other parts of the poem. ${ }^{37}$ That Spenser expects the epitome of fairy history to function in a similar fashion - providing a set of criteria by which to evaluate the deeds of The Faerie Queene's questing knights and ladies — is suggested by specific language used to describe Artegall's adventures in book 5. In the proem to book 5, for example, the narrator describes Justice as "Resembling God in his imperiall might" (5.Proem.10). Moreover, Justice has achieved and

\footnotetext{
${ }^{35}$ Wheare, 79. Eutropius, 1993, xlv, notes that the Epitome of Livy, more specifically, was probably written during the reign of Tiberius, and did not explicitly make the claim to represent Livy's original monumental work, but rather served as a loose adaptation of Livy for the use of "school teachers, writers, rhetoricians, and orators." See also Sanders.

${ }^{36}$ Lewis, 335 .

${ }^{37}$ In fact, many of these "allegorical cores" — such as the scene of reading in the House of Alma, the description of the Garden of Adonis, and the dancing at Mount Alcidale are explicitly introduced as abridged scenes by the Spenserian narrator. Ibid., 353, focuses on what he imagines as Spenser's poetic method, conjecturing that "Spenser was in the habit of writing his 'cores' first and then draping the rest around them." That Spenser prefaces such allegorical cores with evocations of long work, leisure, and labor suggests that he saw the potential for a rhetoric of epitome to serve as a readily recognizable cue signalling the dynamic interplay of part to whole. Cook, 129 , takes up the idea that certain units of the poem - from individual words to entire cantos — seem to be designed to activate the reader's typological sensibilities: having the special capacity to expand exponentially in the mind of the reader, each core can be distinguished from "its neighbors at the same time that it continues to function within the primary matrix these neighbors define."
} 
maintained this imperial status through the conquering might of her agents Hercules and Bacchus, to whom book 5's hero Artegall is compared:

Such first was Bacchus, that with furious might

All th'East before untam'd did overronne ...

Next Hercules his like ensample shewed,

Who all the West with equall conquest wonne. (5.1.2.1-2, 6-7)

The language used here to describe the imperial domain of Justice echoes the language found in the abridged Antiquitee: "The first and eldest, which that scepter swayd, / Was Elfin; him all India obayd, / And all that now America men call" (2.10.72.4-6). Although it is possible to establish this initial parallel, the account of Artegall's adventures does not, in fact, mirror in full the terms set forth by the fairy epitome. ${ }^{38}$ While the opening of book 5 presents Artegall as a conquerer - and in this way thematically akin to the fairy conquerers - he ultimately fails to move to the culminating act of civic edification. In fact, rather than representing Artegall as a builder of cities or bridges, book 5 provides vivid details of his very material destruction of existing structures. For example, after defeating Pollente, Artegall and Talus proceed on to the castle where his daughter Munera has barricaded herself. After chopping off Munera's hands and feet,

lastly all that Castle quite [Talus] raced,

Even from the sole of his foundation,

And all the hewen stones therof defaced,

That there mote be no hope of reparation,

Nor memory thereof to any nation. $(5 \cdot 2 \cdot 28.1-5)$

Whether Spenser means to condone or to condemn Artegall's actions is a question critics usually address by looking to parallels between Artegall and Spenser's employer in Ireland, Lord Grey. After rescuing Irena from the tyrant Grantorto, Artegall is "through occasion called away" (5.12.27.2) by Gloriana, just as Lord Grey was recalled by Elizabeth in 1582 to face an official inquiry into his actions as Lord Deputy Governor of Ireland. Such

\footnotetext{
${ }^{38}$ To assert some sort of thematic connection between books 2 and 5 is hardly a novel claim; an analysis of how the second half of The Faerie Queene deepens its consideration of the potential of the epitome form confirms what many readers have intuited as a basic structural dynamic. As Nohrnberg has shown in comprehensive detail, books 4 to 7 consistently revisit thematic and rhetorical issues laid out initially in books 1 to 3 , and teach the reader not to expect principles of narrative coherence, but rather systems of correspondence, to knit together disparate books of the poem.
} 
historical interpretations of Artegall in effect connect the poem to the Anglo-Irish context in which it was produced - certainly a reading strategy encouraged by the allegorical nature of book $5 .{ }^{39}$ However, the reader who has successfully internalized the principles found in the fairy epitome is invited to situate Artegall within an alternative context. The epitome in effect provides a syntactical principle by which to put Artegall in his proper place within a summarized story of empire.

Artegall may defeat giants and tyrants, but the reader has to look to others to perform the acts of civic edification that mark the qualitative progression encoded in the fairy epitome. Interestingly enough, the character within The Faerie Queene who is able to succeed Artegall in the manner set forward by the fairy epitome is Britomart. Initially presented as both dynastic progenitor and "warlike Maide" (5.7.12.1), both her dynastic desires and her heroic traits drive Britomart to seek out the imprisoned Artegall and do battle with his captor, the Amazon Radigund. Britomart and Radigund are described, in typical heroic terms, as a "Tygre and a Lionesse" (5.7.30.1) and fight until

all the grassie flore

Was fild with bloud, which from their sides did flow,

And gushed through their armes, that all in gore

They trode, and on the ground their lives did strow,

Like fruitless seede, of which untimely death should grow. (5.7.31.5-9)

However, a glance back to book 3 reveals that Britomart manifests a keen awareness of the need for a dynastic telos, and a knowledge that the martial violence that accompanies it will give way to a more all-encompassing civic focus.

Specifically, Britomart's interchange with Paridell in book 3 reflects her abiding interest in the translation of empire as it is manifested through the building of cities. Before being provided with her insights, however, the reader is subjected to Paridell's ideas about the uses of history. As Britomart looks on, Paridell recites his connection to an epic past in order to seduce Hellinore, the young wife of the jealous Malbecco. Having already flirted in secret with Hellinore through signs traced in spilled wine, Paridell obliges Hellinore's request that he "tell / Of deeds of armes, which unto them became, / And every one his kindred, and his name" (3.9.32.3-5). He responds by boasting of his lineal connection to Paris,

\footnotetext{
${ }^{39}$ Scholarship that helps to place Spenser's work within a sixteenth-century Anglo-Irish context includes works by Highley; Canny; Maley.
} 
by whome

That warre was kindled, which did Troy inflame,

And stately towres of Ilion whilome

Brought unto balefull ruine. ... (3.9.34.1-4)

Paridell claims, specifically, to derive his lineage from Parius, the son of Paris and Oenone, born a full ten years before the Trojan War. Parius then left Troy and ultimately built a city "by the Ponticke shore" that he left to "Paridas his sonne / From whom I Paridell by kin descend" (3.9.37.5-6). In essence, Paridell has reshaped a received epic narrative in order to assert the precedence of his own lineage as an important story that unfolds out of the past. ${ }^{40}$

Paridell's evocation of his "worthy" ancestor Paris serves as secret signal to Hellinore of his lustful intentions, and ultimately his version of Trojan history serves a supremely selfish agenda. As Hellinore listens, she is transformed by Paridell's story into a kind of debased Dido who begins to fashion "a world of fancies evermore / In her frail wit" (3.9.52.4-5). ${ }^{41}$ As the parallels in names - Paris-Paridell, Helen-Hellinore - suggest, Paridell not only topples the marriage of Malbecco and Hellinore; he also wreaks parodic havoc upon the authoritative account of which ancestral narratives are worthy enough to be traced out of the ashes of Troy.

While Paridell's account of Trojan history reflects his understanding of history "not as an indication of destiny but as something that may be conveniently rearranged for the sake of the present moment," Britomart clearly resists Paridell's vision by trying to bring attention back to what she clearly considers history's proper emphasis. ${ }^{42}$ To some extent Britomart does indicate her conservative interest in the race from which the British are "lineally extract" (3.9.38.7), thus marking her exemplary status as an "imaginative descendent of Aeneas" who keeps in mind her larger "historical responsibility." "33 Yet, Britomart's emphasis on the imperial succession of cities rather than rulers makes her an embodiment of a subtly updated epic sensibility. Whereas Paridell diminishes the power of epic by sticking close to an articulation of genealogical succession, Britomart maintains a different emphasis upon how the translation of empire is manifested in the

\footnotetext{
${ }^{40} \mathrm{King}, 71$, discusses the way in which Paridell produces a parodic reelaboration of epic around the narrative conventions of fabliaux. Galbraith, 52-74, focuses on how Paridell debases his epic source through imitation.

${ }^{41}$ Dubrow discusses Paridell's account and makes the troubling point that this version of Trojan genealogy is recited by a rapist.

${ }^{42} \mathrm{O}$ 'Connell, 86.

${ }^{43} \mathrm{Ibid}$.
} 
founding of imperial cities. ${ }^{44}$ She shows her passionate civic awareness by celebrating the rise, after Troy and Rome, of Troynovant, that "in all glory and great enterprise, / Both first and second Troy shall dare to equalise" (3.9.44.8-9). She dwells lovingly upon the history of this city, describing how it "with the waves / Of wealthy Thamis washed is along" (3.9.45.1-2), and how

The Troian Brute did first that citie fownd, And Hygate made the meare thereof by west, And Overt gate by North; that is the bownd

Toward the land; two rivers bownd the rest. (3.9.46.1-4)

In elaborating the details of a city's history, Britomart does not directly disavow the importance of a lineal narrative. Rather, her interchange with Paridell clarifies how each makes a different part of a traditional epic historiography stand for the whole. Spenser seems to suggest that given the inevitability of adaptation by way of reduction, Britomart's choice to focus on civic matters is to be preferred to Paris's lineal manipulations.

In fact, the reader is given an opportunity to see how Britomart, armed with this sense of the importance of cities and their history, actively moves from martial acts to contributing to a civil order. In book 5, Britomart first kills Radigund and is praised as "noble Conqueresse" (5.7.36.1), but she then prevents Talus from completing his slaughter of the inhabitants of the city Radegone, and instead works to restore civic order. Britomart actually manages to turn warriors into civic magistrates:

For all those Knights which long in captive shade Had shrowded bene, she did from thraldome free; And magistrates of all that city made,

And gave to them great living and large fee. (5.7.43.1-4)

The knight's questing may never be done - Britomart by necessity continues on her way without being able to rest in union with her dynastic partner - but she leaves behind a reconstituted city. Although initially she is strongly linked to a narrowly defined dynastic narrative, Britomart actually comes to embody the same shift from martial to civil rule that the fairy epitome so values.

\footnotetext{
${ }^{44}$ Galbraith, 64, sees Britomart's civic interests as gestures towards the "prophetic" and "apocalyptic" that ultimately contribute to Spenser's linkage of translatio to a typological refiguration of the relation of England and Rome.
} 
Spenser is typically thought of as an epic poet who foregrounds the struggle involved in representing dynastic lineage as the historical core that gives to epic a shape and direction. In many ways the abridged Antiquitee supports this understanding of Spenser's ambivalent relation to epic: under the guise of conservative redaction his version of fairy history actually breaks apart the ligatures of a lineal narrative. Spenser's use of the epitome form makes clear how different historical modes could provide viable alternatives to the "genealogical theme" that traditionally served as epic's "standard apparatus." 45

Ultimately, Spenser's exploration of alternatives to a dynastic historiography has implications for the definition of his epic task. In one sense, inclusion of the epitome within The Faerie Queene perpetuates a logic of compendious coverage that was wholly typical of Renaissance epic. The fairy history's presence marks Spenser's own mastery of the epitome form as a historiographic mode, and his capacity to create a redaction more elegantly economical than even the most skeletal of dynastic lists, and more tightly constructed than the most succinct of imperial histories - in effect, the epitome of epitomes. Spenser in this way proves his ability to incorporate and absorb many different types of historical writing. However, it is also possible to read the fairy epitome as the historiographic core that enables readers to cut through the compendious matter of The Faerie Queene itself. In this sense the abridged Antiquitee reflects Spenser's sensitivity to the changing needs of a Renaissance readership, and his acute awareness of how, in taking up the role of epic poet in an age of print, he was competing with those epitomists who promised to provide readers with less matter and more art.

Trinity College

${ }^{45}$ King, 60 . 


\section{Bibliography}

The Abridgement of the Booke of Assises. London, [1565?]

Anderson, Judith H. "What Comes After Chaucer's But: Adversative Constructions in Spenser." In Acts of Interpretation: The Text in its Contexts, 700-1600: Essays on Medieval and Renaissance Literature in Honor of E. Talbot Donaldson, ed. Mary J. Carruthers and Elizabeth D. Kirk, 10518. Norman, OK, 1982.

. "The Antiquities of Fairyland and Ireland." Journal of English and Germanic Philology 86, no. 2 (1987): 199-214.

Armitage, David. "Literature and Empire." In The Origins of Empire: British Overseas Enterprise to the Close of the Seventeenth Century, ed. Nicholas Canny, 99-123. Oxford, 1998.

Ascham, Roger. The Scholemaster. London, 1570.

Baldwin, Thomas Whitfield. William Shakspere's Small Latine \& Lesse Greeke. 2 vols. Urbana, 1944.

Berger, Harry. The Allegorical Temper: Vision and Reality in Book II of Spenser's 'Faerie Queene'. New Haven, 1957.

Cain, Thomas H. Praise in 'The Faerie Queene'. Lincoln, 1978.

Canny, Nicholas P. The Elizabethan Conquest of Ireland: A Pattern Established, 1565-76. New York, 1976.

Capito, Wolfgang. An Epitome of the Psalmes. Trans. Richard Tauerner. London, 1539.

Carpenter, Frederic Eves. "Spenser Apocrypha." In The Manly Anniverary Studies in Language and Literature, 64-69. Chicago, 1923.

Christian, Margaret. "The ground of Storie': Genealogy in The Faerie Queene." Spenser Studies 9 (1991): 61-79.

Cicero, Marcus Tullius, Roger Ascham et al. A Panoplie of Epistles, or, a Looking
Glasse for the Unlearned. Trans. Abraham Flemming. London, 1576.

Colie, Rosalie Littell. The Resources of Kind: Genre-Theory in the Renaissance. Ed. Barbara K. Lewalski. Berkeley and Los Angeles, 1973.

Cook, Patrick J. Milton, Spenser, and the Epic Tradition. Aldershot and Burlington, VT, 1996.

Curran, John. Roman Invasions: The British History, Protestant Anti-Romanism, and the Historical Imagination in England, 1530-1660. Newark, DE and London, 2002.

Donoghue, Denis. Thieves of Fire. New York, 1974.

Dubrow, Heather. "The Arraignment of Paridell: Tudor Historiography in The Faerie Queene, III.ix." Studies in Philology 87, no. 3 (1990): 312-28.

Eutropius. A Briefe Chronicle.... Trans. Nicholas Haward. London, 1564.

—. A Breviary of Roman History.... London, 1684.

- The Breviarium Ab Urbe Condita of Eutropius: The Right Honourable Secretary of State for General Petitions: Dedicated to Lord Valens, Gothicus Maximus \& Perpetual Emperor. Ed. and trans. H. W. Bird. Liverpool, 1993.

Fichter, Andrew. Poets Historical: Dynastic Epic in the Renaissance. New Haven, 1982.

Fletcher, Angus. The Prophetic Moment: An Essay on Spenser. Chicago, 1971.

Galbraith, David. Architectonics of Imitation in Spenser, Daniel, and Drayton. Toronto and Buffalo, 2000.

Galen. Galens Bookes of Elementes, As They $B e$ in the Epitome. Trans. John Jones. London, 1574.

Helgerson, Richard. Self-Crowned Laureates: Spenser, Jonson, Milton and the Literary System. Berkeley, 1983. 
Forms of Nationhood: The Elizabethan Writing of England. Chicago, 1992.

Highley, Christopher. Shakespeare, Spenser, and the Crisis in Ireland. Cambridge and New York, 1997.

Hough, Graham. A Preface to The Faerie Queene. New York, 1962.

Justinus, Marcus Junianus, and Pompeius Trogus. The Abridgement of the Historyes of Trogus Pompeius. Trans. Arthur Golding. London, 1578.

Justinus, Marcus Junianus. The History of Justin, Taken Out of the Four and Fortieth Books of Trogus Pompeius: Containing the Affairs of all Ages and Countrys, both in Peace and War, from the Beginning of the World Until the Time of the Roman Emperors. Trans. Robert Codrington. London, 1682.

King, Andrew. "Lines of Authority: The Genealogical Theme in The Faerie Queene." Spenser Studies 18 (2003): 59-77.

Lanquet, Thomas. An Epitome of Chronicles ... Continued ... by Thomas Cooper. London, 1549.

Levy, F. J. Tudor Historical Thought. San Marino, 1967.

Lewis, C. S. The Allegory of Love: A Study in Medieval Tradition. New York, 1938.

Maley, Willy. A Spenser Chronology. Lanham, MD, 1993.

Manley, Lawrence. Literature and Culture in Early Modern London. Cambridge and New York, 1995.

Miller, Jacqueline T. "The Status of Faeryland: Spenser's 'Vniust Possession." Spenser Studies 5 (1985): 31-44.

Mills, Jerry Leath. "Prudence, History and the Prince in The Faerie Queene, Book II." Huntington Library Quarterly 41 (1978): 83-101.

Minsheu, John. Ductor in Linguas. London, 1625.

Murrin, Michael. "The Audience of The Faerie Queene." Explorations in Renaissance Culture 23 (1997): 1-21.
Nohrnberg, James. The Analogy of 'The Faerie Queene'. Princeton, 1976.

O'Connell, Michael. Mirror and Veil: The Historical Dimension of Spenser's 'Faerie Queene'. Chapel Hill, 1977.

Ortelius, Abraham. An Epitome of Ortelius His Theater of the World. . . L London, 1601.

Oxford Dictionary of National Biography. Ed. H. C. G. Matthew and Brian Harrison. 60 vols. Oxford and New York, 2004.

Raleigh, Sir Walter, and Alexander Ross. The Marrow of Historie, Or, an Epitome of all Historical Passages from the Creation to the End of the Last Macedonian War. London, 1650.

Rambuss, Richard. Spenser's Secret Career. Cambridge and New York, 1993.

Read, David. Temperate Conquests: Spenser and the Spanish New World. Detroit, 2000.

Roche, Thomas P., Jr. 'The Kindly Flame': A Study of the Third and Fourth Books of Spenser's 'Faerie Queene'. Ann Arbor, 1964.

Rogers, Richard. The Practice of Christianitie. . . . London, 1618.

Rossi, Joan Warchol. "Briton moniments: Spenser's Definition of Temperance in History." English Literary Renaissance 15, no. 1 (1985): 42-58.

S., E. De Rebus Gestis Britanniae. . . . London, 1582.

Sanders, Henry A. Roman Historical Sources and Institutions. New York and London, 1967.

Saunders, J. B. de C. M., and Charles D. O'Malley. The Illustrations from the Works of Andreas Vesalius of Brussels. New York, 1950.

Scoloker, Anthony. A Bryefe Summe of the Whole Byble. London, [1549?]

Smith, Sir William. A New Classical Dictionary of Biography, Mythology, and Geography, Partly Based upon the Dictionary of Greek and Roman Biography and Mythology. London, 1850. 
Spenser, Edmund. The Faerie Queene. Ed. A. C. Hamilton. New York, 2001.

Stewart, Alan, and Garrett A. Sullivan, Jr. "'Worme-eaten, and full of canker holes': Materializing Memory in The Faerie Queene and Lingua." Spenser Studies 17 (2003): 215-38.

Stow, John. A Summarie of Englyshe Chronicles.... London, 1565.

Summit, Jennifer. "Monuments and $\mathrm{Ru}$ ins: Spenser and the Problem of the English Library." English Language History 70, no. 1 (2003): 1-34.

Van Es, Bart. Spenser's Forms of History. Oxford and New York, 2002.

Vesalius, Andreas. Compendiosa Totius Anatomie Delineatio. London, 1545.

Webster, John. "Challenging the Commonplace: Teaching as Conversation in Spenser's Legend of Temperance." In Approaches to Teaching Spenser's 'Faerie Queene', ed. David Lee Miller and Alexander Dunlop, 82-92. New York, 1994.

Wheare, Degory. The Method and Order of Reading both Civil and Ecclesiastical Histories. . . . London, 1685.

White, Hayden V. The Content of the Form: Narrative Discourse and Historical Representation. Baltimore, 1990.

Williams, Kathleen. Spenser's World of Glass: A Reading of 'The Faerie Queene'. Berkeley and Los Angeles, 1966.

Woodcock, Matthew. Fairy in The Faerie Queene: Renaissance Elf-Fashioning and Elizabethan Myth-Making. Aldershot, 2004. 